Róża Godula-Węcławowicz

ORCID: https://orcid.org/0000-0002-4657-3539

Instytut Archeologii i Etnologii

Polskiej Akademii Nauk

\title{
Gdy dom nie jest domem. Kraków w cieniu Lwowa
}

\author{
When the home is not a home. Cracow in the shadow of Lvov
}

\begin{abstract}
Forced resettlements were the lot of the generation that had survived the Second World War. Experiences associated with displacement are strongly rooted in the sphere of emotions, thus impacting the formation of the narrative about a lost city and a newly settled city. The interpretive scope of the analysis is delineated by the key category of memory and its derivatives: the community of memory, private memory, the emotional community of memory, as well as trauma and nostalgia. A broad spectrum of terms allows us to refer it to the "lived world“ and the practices of everyday that belonged to the former residents of Lvov who arrived in Cracow after the Second World War, as well as their descendants who identified themselves with the family memory. The emotional community of memory of the „Lvov Cracovians” is described by common indicators: an identical place of origin (not necessarily of birth, however), the war trauma and displacement trauma, later, at varying dates - the process of settling in Cracow. These are the contexts in which their experiences are situated: the burden of losing their homes and their city, the sense of rootlessness, the sense of impermanence and alienation, the nostalgia for abandoned places and bygone times. The half-real, half-metaphysical immersion in the space of Lvov - first mundane and familiar, later brutally appropriated by ideology and politics - caused many former residents of Lvov to feel that their new place of residence Cracow, with all its historical splendour of the cradle of Polishness - did not become a home, even though the values of national culture were very close to their hearts.

That the city of origin is transformed into a myth is not surprising, it is an obvious cultural standard; but the relatively limited presence of Lvov in Cracow is worth investigating. In contrast to Wrocław, whose empty post-war space was filled by immigrants, the well-settled community of Cracow treated the otherness of the newcomers from the East with reserve. In Cracow, the memory of lost Lvov was an alienated one. This cannot be explained solely by the fact that in the official discourse of the People's Republic of Poland the topic of the former Eastern Borderlands of Poland was strictly censored (it is commonly known that, paradoxically, this is precisely what caused the powerful mythicisation of the Borderlands and Borderland cities in the everyday memory of the Polish people). In Wrocław, which was empty of Polish content, the myth of Lvov took a firm root and the city became the heir of the Lvov tradition. Cracow, in contrast, was struggling
\end{abstract}


throughout the post-war period with the ongoing devaluation of its symbolic significance which, although rooted in the Polish national universe, was undergoing ideological manipulation.

The Lvov diaspora was constructing its image of Cracow by means of contrasting it to Lvov. In the family tales, "that" Lvov, surrounded with the glow of nostalgia, was - and still is - a mental refuge, strongly rooted in the memory of the first-generation migrants and the memory passed on to children and grandchildren brought up in the new place. It became a symbolic place and, like with Hemingway's Paris, there is never any ending to it.

Key words: memory, emotional community of memory, nostalgia, trauma, displacement, Lvov, Cracow, image of the city

Przesiedlenia były udziałem pokolenia, które przeżyło czas II wojny światowej. Przeżycia z tym związane są mocno zakorzenione w sferze emocji wpływających na kształtowanie opowieści o mieście utraconym i o mieście nowego osiedlenia. Zakres interpretacyjny analizy wyznacza kluczowa kategoria pamięci i jej pochodne: wspólnota pamięci, pamięć prywatna, emocjonalna wspólnota pamięci oraz trauma i nostalgia. Szerokie spektrum terminów upoważnia, by odnieść je do świata przeżywanego i praktyk życia codziennego, jakie były udziałem lwowian przybyłych do Krakowa po drugiej wojnie światowej oraz ich potomków utożsamiających się z rodzinną pamięcią. Emocjonalną wspólnotę pamięci „lwowskich krakowian” określa kilka wyznaczników: tożsame miejsce pochodzenia (niekoniecznie - urodzenia), trauma wojny i wysiedlenia, późniejsze zamieszkanie w Krakowie (w różnym czasie). W tych kontekstach sytuują się ich doświadczenia i przeżycia - piętno utraty własnego domu i miasta, brak zakorzenienia, poczucie tymczasowości, wyobcowania, tęsknota za dawnym miejscem i czasem. Na poły realne, na poły metafizyczne zanurzenie w przestrzeni Lwowa, dotychczas codziennej i swojskiej, a potem gwałtownie zawłaszczonej przez ideologię i politykę spowodowało, że dla wielu lwowian nowe miejsce zamieszkania - Kraków z historycznym splendorem matecznika polskości - nie stało się domem, mimo że wartości kultury narodowej były im bardzo bliskie.

Mityzacja rodzinnego miasta nie zaskakuje, to oczywista prawidłowość kulturowa, warto natomiast rozważyć stosunkowo nikłą obecność Lwowa w Krakowie. Inaczej niż we Wrocławiu, którego pustą powojenną przestrzeń wypełnili imigranci, w Krakowie zetknęli się oni z zasiedziałą społecznością, z rezerwą odnoszącą się do inności przybyszy ze wschodu. Pamięć o utraconym Lwowie była w Krakowie pamięcią wyobcowaną. Nie da się tego wytłumaczyć li tylko cenzurowaniem tematyki kresowej w oficjalnym dyskursie epoki Polski Ludowej. Skądinąd przecież wiadomo, że paradoksalnie spowodowało to silną mitologizację Kresów i miast kresowych w potocznej świadomości Polaków. W pozbawionym polskich treści Wrocławiu mit Lwowa zagnieździł się na dobre i miasto stało się spadkobiercą lwowskiej tradycji. Tymczasem Kraków w latach powojennych zmagał się z procesem dewaluacji swego symbolicznego znaczenia, wprawdzie zakorzenionego w polskim uniwersum narodowym, ale podlegającego ideologicznym manipulacjom.

Diaspora lwowska budowała obraz Krakowa przez przeciwieństwo do Lwowa. W rodzinnych przekazach tamten Lwów, owiany nutą nostalgii, był i jest mentalną ostoją mocno osadzoną we własnej pamięci pierwszego pokolenia migrantów i pamięci przekazanej dzieciom i wnukom wychowanym już w nowym miejscu. Stał się miejscem symbolicznym i niczym Paryż Hemingwaya - nigdy nie ma końca.

Słowa kluczowe: pamięć, emocjonalna wspólnota pamięci, nostalgia, trauma, wysiedlenie, Lwów, Kraków, wizerunek miasta

Odebrano / Received: 31.01.2019

Zaakceptowano / Accepted: 27.08.2019 
W słońcu kończącego się lata 2005 roku po raz pierwszy zwiedzałam Lwów, potem tych wyjazdów było jeszcze kilka. Pojechałam zobaczyć miasto, które nie było obecne $\mathrm{w}$ imaginarium mojej rodziny, tak po kądzieli jak i po mieczu, gdyż zakorzenieni jesteśmy w Krakowie, w miasteczkach Małopolski, Lanckoronie i Tuchowie, oraz na Zaolziu. Oczywiście ciekawiło mnie miasto zajmujące poczesne miejsce w kontekście narodowej pamięci Polaków, wpisane w wieloaspektowy mit Kresów. W polskiej mitologizacji utrwalone jako Semper Fidelis Poloniae, swoisty fenomen wierności Rzeczpospolitej, oraz Leopolis Multiplex, wielokulturowej i etnicznej wspólnoty, gdzie zgodnie mieli żyć Polacy, Żydzi, Rusini, Ormianie, Austriacy i Niemcy. A przede wszystkim - uosobienie mitu Kresów jako utraconej Arkadii. Ale była jeszcze inna przyczyna tej podróży. Towarzyszyłam mężowi, który po raz pierwszy odwiedził rodzinną miejscowość rodziców i dziadków. Wówczas przed nami były wyjazdy do jeszcze kilku bliskich miejsc rozsianych na Kresach południowo- i północno-wschodnich, także na Zaolziu. Może je kiedyś opiszę.

Wspomniana podróż miała określony program zabytkoznawczy (pojechaliśmy $\mathrm{w}$ licznej grupie znajomych i nieznajomych $\mathrm{z}$ różnych stron Polski związanych z konserwacją i ochroną zabytków oraz z rewitalizacją miast). Na pozór relaksująca wyprawa, była w istocie refleksyjna i pełna emocji. Gdy zbliżaliśmy się do Lwowa, co rusz ktoś włączał przedwojenny szlagier, piosenkę z charakterystycznym śpiewnym akcentem, archiwalne fragmenty „Wesołej Lwowskiej Fali” ze Szczepciem i Tońkiem mówiących batakiem. Obejrzeliśmy dokumentalny film, który przypomniał najważniejsze wydarzenia z dawnej i najnowszej historii miasta. Nostalgiczna podróż w przeszłość spowodowała zmianę atmosfery $\mathrm{w}$ autokarze. Początkowo niezobowiązująca, wręcz wesoła, stawała się coraz bardziej wyciszona i poważna. A już we Lwowie, podczas zwiedzania te niespodziewane zatrzymania przy mijanym zaułku, na jakiejś ulicy, przy kamienicy niczym niewyróżniającej się z otoczenia, to zaglądanie na zwykłe podwórka, te chwile zadumy. I nade wszystko wrażenia wymieniane w czasie wieczornych spotkań uświadomiły mi, że owa podróż dla większości miała też wymiar bardzo osobisty, nie tylko dla nas. Szukano śladów przerwanej historii rodziny, odwiedzając indywidualne miejsca pamięci. Ja niespiesznie spacerowałam po Lwowie międzywojennym, zapisanym w tradycji rodzinnej mego męża. Od urodzenia żył wprawdzie w Krakowie, ale dzięki rodzinnym opowieściom wyobrażeniowo przechadzał się po ulicach Lwowa, podziwiał jego architekturę, bawił się w Stryjskim Parku, zjeżdżał na sankach z Wysokiego Zamku, zajadał ciastka i lody w cukierniach Zalewskiego i Krzysztofowicza, odwiedzał dziadków Polatyńskich na ulicy Hoffmana i pradziadków Węcławowiczów na Głowackiego. A w dorosłym życiu, gdy po raz pierwszy odwiedziliśmy Lwów, oprowadzał mnie, nie zaglądając do aktualnego planu, który na wszelki wypadek miałam w torebce. W ogóle nie był potrzebny. Równocześnie notowałam w pamięci wyraziste oblicze współczesnego miasta - wszechobecną komercję, zalew krzykliwych reklam, w których język ukraiński przenikał się z angielskim, pulsujący rytm wieczornego i nocnego życia, kawiarniany 
i knajpkowo-ludyczny przypominający miasta z południa Europy. Niezrozumiałe kontrasty - pieczołowicie odnowione dzieła architektury obok innych popadających w ruinę, a przecież równie lub bardziej wartościowych z konserwatorskiego punktu widzenia. Zaskoczył mnie urbanistyczny rozmach historycznego centrum, ale najbardziej - stosunkowo niewielka ingerencja radzieckich budowniczych w jego tkankę. Dostrzegłam też narodowe akcenty uwypuklające ukraińską tożsamość miasta, współczesną i sięgającą daleko w głąb historii.

Etnologiczną „podróż” do czasu przeszłego, której zalążkiem jest ta przywołana na wstępie, wyznacza kluczowa kategoria pamięci i jej pochodne. Celem owej podróży, sensownej lub, jak powiada Marc Augé, prawdziwej, przeciwstawiającej się podróży turystycznej, która nie wnosi nic do poznania ${ }^{1}$, jest analiza wizerunków Lwowa i Krakowa okrzepłych w sferze prywatnej wspólnoty pamięci „lwowskich krakowian”. Za Lechem Nijakowskim przyjmuję, że wspólnota pamięci charakteryzuje osoby, „które łączy określone doświadczenie biograficzne, nie zawsze o charakterze traumatycznym, oraz ich potomków, którzy przejęli pamięć rodzinną”2. Pojęciem bliskoznacznym jest „pamięć prywatna (...) przechowywana $\mathrm{w}$ rodzinnych opowieściach, zdjęciach pamiątkowych i interpretacjach wydarzeń zbiorowych"'3. W tych kontekstach sytuują się doświadczenia i wspomnienia owych „lwowskich krakowian”, czyli lwowian zamieszkałych w Krakowie po drugiej wojnie światowej i ich potomków, którzy z pamięcią rodzinną się utożsamiają i, zapożyczając stwierdzenie Jacka Nowaka, „uporczywie ją przerabiają”4.

W badaniach nad pamięcią coraz częściej akcentuje się rolę specyficznej formy doświadczenia rzeczywistości, jaką jest przeżycie wytwarzające różnego rodzaju emocje pozytywne i negatywne. O wspólnotach pamięci, lokalnych i narodowych, jako wspólnotach emocjonalnych pisała Joanna Kurczewska (rozwijając koncepcję Barbary Rosenwein ${ }^{5}$ :

Właśnie one - $\mathrm{i}$ to bez względu na to, czy są to wspólnoty tradycyjne czy sieciowe, wyobrażone czy realne - są nastawione na odczuwanie i wartościowanie więzi międzyludzkich, i to w taki sposób, że odnoszą się do szerokiego zakresu emocji pozytywnych i negatywnych ${ }^{6}$.

Emocjonalna wspólnota pamięci kieruje w stronę jeszcze dwóch pojęć przydatnych w niniejszej analizie: traumy i nostalgii. Jak to bywa w humanistyce, zostały już one wielokrotnie przedefiniowane, rozszerzone lub uściślone, zresztą nie miejsce tu na krytyczne ich omówienie. Traktowane jako narzędzia analityczne są użyteczne jako „koncept

\footnotetext{
1 Paquot 2006, s. 14.

2 Nijakowski 2008, s. 145.

3 Golka, 2009, s. 32-33.

4 Nowak 2011, s. 9.

5 Rosenwein 2006; Rosenwein 2010.

6 Kurczewska 2016, s. 31.
} 
otwarty", czyli otwarty model, mogący poszerzyć naukowe postrzeganie i interpretacje znaczących procesów społecznych ${ }^{7}$. Jeffrey C. Alexander wprawdzie odniósł tę uwagę do traumy kulturowej, lecz z powodzeniem, jak sądzę, obejmuje ona i drugą kategorię. Badacz podkreśla przyczynowo-skutkowe związki między traumatycznym wydarzeniem i pamięcią o nim:

Trauma kulturowa ma miejsce wtedy, gdy członkowie zbiorowości czują, że zostali poddani przerażającemu wydarzeniu, które pozostawia niezatarte ślady w świadomości grupowej, oznaczając ich wspomnienia na zawsze i zmieniając ich przyszłą tożsamość na podstawowe i nieodwołalne sposoby ${ }^{8}$.

Neil J. Smelser podobnie rozumie traumę jako rezultat wydarzenia naruszającego egzystencję grupy, istotne dla niej wartości i znaczenia. Pamięć traumy jest kulturowym procesem, rozciągającym się w czasie ${ }^{9}$. Zdaniem Piotra Sztompki stan swoistej traumy powoduje każda zmiana społeczna, albowiem podważa ustalony porządek życia społecznego, poczucie zakorzenienia w systemie trwałych wartości, norm, narusza dotychczasowy stan równowagi ${ }^{10}$. A sama trauma społeczna jest nagła i szybka, radykalna, głęboka, wszechstronna i dotyka samej istoty życia społecznego. Postrzegana jest jako narzucona, zewnątrzpochodna, jako coś, co nam się przydarza, staje na naszej drodze, nadto jawi nam się jako coś nieoczekiwanego, nieprzewidzianego, zaskakującego, szokującego, a nawet odrażającego ${ }^{11}$.

Bliska traumie, ale nie tożsama $\mathrm{z}$ nią, jest nostalgia. Fenomen nostalgii jest bardzo pojemny, zawiera wiele propozycji badawczych. Podążam za ustaleniami Swietłany Boym, która widziała nostalgię całościowo jako postawę wobec przeszłości i zarazem narrację o niej. Określiła ją jako „tęsknotę za domem, który już nie istnieje lub nigdy nie istniał. Nostalgia to doznanie utraty i wysiedlenia, ale jest to także romans z własną fantazją. Nostalgiczna miłość może przetrwać tylko w związku na odległość"12. Nadto Boym wskazała, że „nostalgia dotyczy relacji między indywidualną biografią a biografią grup lub narodów, między pamięcią osobistą i zbiorową"13.

Szerokie spektrum obu terminów - nostalgii i traumy - upoważnia, by odnieść je do świata przeżywanego i praktyk życia codziennego, jakie były udziałem mieszkańców Lwowa, którzy opuścili miasto podczas II wojny światowej lub kilka lat po niej, oraz ich

\footnotetext{
${ }^{7}$ Alexander 2004, s. 4.

${ }^{8}$ Alexander, 2004, s. 1.

${ }^{9}$ Smelser 2004.

${ }^{10}$ Sztompka 2002, s. 456.

${ }^{11}$ Sztompka 2000, s. 22.

${ }_{12}$ Boym 2001, s. 10 i n.

13 Boym 2001, s. 10 i n.
} 
potomków utożsamiających się z rodzinną pamięcią ${ }^{14}$. Emocjonalną wspólnotę pamięci „lwowskich krakowian” określa kilka wyznaczników: tożsame miejsce pochodzenia (niekoniecznie - urodzenia), trauma wojny i wysiedlenia, późniejsze zamieszkanie w Krakowie (w różnym czasie). Wojenne przeżycia lwowskich Polaków zawierają się pomiędzy dwoma okupacjami sowieckimi (1939-1941 i 1944-1945) przedzielonymi okupacją niemiecką (1941-1944). Nie będą tu przedmiotem szczególnej uwagi, lecz nie sposób o nich nie wspomnieć, gdyż ogniskują narracyjną przestrzeń pamięci przesiedleńców i kolejnych pokoleń. Wojna i w jej konsekwencji wysiedlenie jest mocną cezurą czasową w biografiach, po niej - jak lapidarnie ujęła to Irena Dziedzic, jedna z lwowskich krakowianek:

Już nic nigdy i nigdzie nie było takie samo ${ }^{15}$. (...) Czasy szkolne - to jedno wspomnienie, a wojna i zmieniający się okupanci, szkoła w tym czasie, ograniczenia, niedostatek, strach przed wywózkami za <<pierwszych ruskich >>, strach przed lapankami niemieckimi, ukraiński terror za <<drugich ruskich >>, i w tym borykająca się z codziennością moja matka Wieczne Zmartwienie ${ }^{16}$.

W rodzinie mojego męża najbardziej utrwalona jest opowieść o śmierci stryja, wtedy dwudziestojednoletniego, postrzelonego przez Niemców w maju 1944 roku w czasie akcji bojowej grupy szturmowej Szarych Szeregów, której był dowódcą ${ }^{17}$. Będąc we Lwowie poszliśmy na Zadworzańską, by w rzeczywistej przestrzeni ulicy osadzić miejsce tragedii. Natomiast kolega bezskutecznie szukał rodzinnej posesji, gdzie jako dziecko ostatni raz widział ojca uciekającego przed aresztowaniem przez sowiecką agenturę. Inna uczestniczka naszej wycieczki codziennie szła na Rynek, by choć przez chwilę popatrzeć na kamienicę zarekwirowaną przez enkawudzistów w roku 1945, lecz nie ośmieliła się do niej wejśćc ${ }^{18}$.

Wskutek pojałtańskiego podziału Europy Lwów znalazł się w granicach Związku Radzieckiego, w ciągu kolejnych miesięcy kończącej się wojny nastąpił wielki exodus polskiej ludności. Zdecydował o nim przymus sytuacyjny, który pokrótce zrelacjonował jeden z wychodźców, Zdzisław J. Zieliński, późniejszy współzałożyciel Towarzystwa Miłośników Lwowa:

${ }^{14}$ Opieram się na opublikowanych wspomnieniach lwowian oraz na własnych rozmowach i obserwacjach, które prowadziłam w różnym czasie i przy różnych nadarzających się okazjach, np. spotkania towarzyskiego czy odbywanej podróży. Oznaczam je: RGW mat. własne.

15 Dziedzic 1992, s. 103. Irena Dziedzic (1925-2018), znana dziennikarka i prezenterka telewizyjna, twórczyni pierwszego polskiego talk-show „Tele-Echo” (1956-1981). Ze Lwowa do Krakowa przyjechała jednym z pierwszych transportów repatriacyjnych razem z matką, od 1948 r. mieszkała w Warszawie.

${ }^{16}$ Dziedzic 1992, s. 98.

${ }^{17}$ Jerzy Węcławowicz, urodzony 5 maja 1923. Ciężko ranny zabrany został z ulicy przez Gestapo i jego dalszy los jest nieznany.

${ }^{18}$ RGW mat. własne. 
Do wyjazdów nikt nas oficjalnie nie zmuszał, nie było też żadnych oficjalnych zarządzeń wszystko to miało w zasadzie charakter dobrowolny. Natomiast oficjalna propaganda nie pozostawiała cienia wątpliwości co do przynależności Lwowa i Kresów Wschodnich. Owszem, ułatwiano wyjazdy, stwarzając dla nich „dogodne” warunki. Polski Urząd Repatriacyjny (PUR) przy ul. Dąbrowskiego przyjmował zgłoszenia na wyjazd. Po odstaniu w długim ogonku i wniesieniu odpowiedniej opłaty należało tylko wyczekiwać właściwego transportu. (...)

Było jednak coś, co wpływało bardzo istotnie na decyzję wyjazdu. To po prostu warunki życia we Lwowie. (...) Przede wszystkim nie było prądu, a więc i światła. We wszystkich instytucjach, nawet w szkołach i szpitalach wojskowych. Ciemne ulice były wręcz niebezpieczne w nocy, ale także w dzień. Spotykało się całe masy rozprzężonego żołdactwa, jak i cywilnych żulików. Napady i kradzieże były na porządku dziennym, a szczególnie nocnym. (...) Miasto było brudne i niebezpieczne - tramwaje rzadkie i przepełnione. $Z$ tego miasta chciało się uciekać! $!^{19}$

Bardziej drastyczny obraz ówczesnej sytuacji we Lwowie utkwił w pamięci rodzinnej Ireny Dziedzic, która w autobiograficznej książce oddała ów stan zagrożenia:

Przecież to ukraiński terror głównie: trupy co rano na ulicach, ludzie wywlekani z domów, aby nigdy nie powrócić, rabunki i gwałty - sprawiły, że Polacy tak szybko, tak tłumnie wyjeżdżali... Towarowymi pociągami, niektórzy bydlęcymi, wyprzedając za grosze, nawet oddając za darmo dorobek pokoleńn ${ }^{20}$.

Choć indywidualne narracje o tym wydarzeniu różnią się w szczegółach, to jednak ci, którzy doświadczyli dramatu wysiedlenia, propagandowo nazwanego przez władze PRL-u repatriacją, bynajmniej nie odczuli go jako powrotu do ojczyzny, bo ojczyzna została za nowo ustanowioną granicą w przedwojennym Lwowie, lecz jako wyrzucenie z niej. Lwowską tożsamość i utratę ojczyźnianego miasta silnie przeżywał Stanisław $\mathrm{Lem}^{21}$, czemu dał wyraz w wielu wywiadach i wspomnieniowych tekstach:

(...) Krzysztof Myszkowski zapytał mnie, czym jest dla mnie Lwów. Odpowiedziałem krótko: Ojczyzną. (...) Jestem lwowianinem i lwowianinem do śmierci pozostanę. Nic się tutaj nie zmieni, ludzie i narody to nie szafa, którą się przesuwa z kąta w ką ${ }^{22}$.

(...) Każdy człowiek ma tylko jedną matkę i nie można jej zmieniać na inną. Dlatego Lwów jest dla mnie niezamienialny. Przed wojną nawet nigdy nie byłem w Warszawie, nigdy nie

${ }^{19}$ Zieliński 1995 , s. 26-27.

${ }^{20}$ Dziedzic 1992, s. 96-101.

${ }^{21}$ Stanisław Lem urodzony we Lwowie w 1921 roku, skąd wyjechał w 1945 i wraz z całą rodziną osiadł w Krakowie. W latach 1983-1988 przebywał na emigracji w Wiedniu. Zmarł w 2006 roku w Krakowie.

${ }^{22}$ Fiałkowski 2000, s. 69, 108. 
widziałem Krakowa. Więc mogę powiedzieć, że Lwów jest częścią mnie, a ja częścią Lwowa. Jestem wrośnięty we Lwów jak drzewo $(. . .)^{23}$.

Emocje z tym związane dotknęły nie tylko pierwszego pokolenia wygnańców, ale i dziedziców rodzinnej pamięci. Traumatyczne wojenne wydarzenia tkwią w pamięci międzypokoleniowej - jako czas przeszły stale obecny w teraźniejszości. Życie rodziców i swoje własne „przecięte na dwie części, przed wyjazdem i po wyjeździe” ze Lwowa sugestywnie opisał poeta Adam Zagajewski ${ }^{24}$ w eseju „Dwa miasta”, mimo że „w tamtym cudownym miejscu” spędził tylko pierwsze cztery miesiące życia: „A jednak gdziekolwiek przetnie się i podzieli życie, przecina się je i dzieli na dwie połowy"25. Kilka lat temu udzielił wywiadu dziennikarce „Gazety Wyborczej”:

Moja rodzina wyjechała ze Lwowa blisko 70 lat temu, 28 października, w dniu imienin ojca, Tadeusza. Miałem cztery miesiące. Po okupacji Lwowa przez Sowietów w latach 1939-41 ludzie już wiedzieli, co to jest Związek Radziecki. Poza tym ojciec był w AK. Jego koledzy zostali aresztowani, miał powody, żeby uciekać.

(...) Lwów przed wojną to było kwitnące miasto. Miało swoje problemy, biedę, nienawiści, ale dla tych, którzy tam żyli, było centrum świata. Nie do pojęcia, że można kogoś tego pozbawić. To dziura, która zostaje na zawsze.

W 1945 r. zostaliśmy rzuceni na Śląsk i wychowywałem się w eks-pruskim mieście.

(...) W moim domu mówiło się, że jesteśmy tu tylko przez pomyłkę, że to Lwów jest naszym miejscem na ziemi. Pokolenie dziadka uważało, że może jeszcze wrócimy. Śląsk to była prowizorka. Miałem się nie przywiązywać do tych drzew i do tej czarnej rzeki, która płynie przez Gliwice. (...)"26.

W tym samym gliwickim domu, piętro niżej, zamieszkała rodzina Pszoniaków z trójką synów, najmłodszy Wojciech ${ }^{27}$ przywołuje rodzinną traumę:

Wychowałem się w dwóch przestrzeniach i musiałem to ciągle konfrontować. Dojmująca była ta tragedia przesiedleńcza, smutek ojca, który tęsknił za Lwowem $(. . .)^{28}$.

${ }^{23}$ Tuzow-Lubański 1996.

${ }^{24}$ Adam Zagajewski, poeta, eseista, laureat wielu nagród krajowych i zagranicznych, od lat jest jednym z kandydatów do nagrody Nobla. Urodzony we Lwowie w 1945 roku, w tym samym roku rodzina Zagajewskich na skutek akcji przesiedleńczej wyjechała ze Lwowa i osiadła w Gliwicach. Tam spędził dzieciństwo, ale największą część swego życia związał z Krakowem - okres studiów i pierwszej pracy zawodowej (lata 60. i 70. XX w.), a po powrocie z emigracji w 2002 roku mieszka tu na stałe.

${ }^{25}$ Zagajewski 2007, s.8.

${ }^{26}$ Zagajewski 2015.

${ }^{27}$ Wojciech Pszoniak, aktor, rocznik 1942, pod koniec II wojny światowej jego rodzina musiała wyjechać ze Lwowa, dorastał w Gliwicach, aktorstwo studiował w Krakowie, w latach 1968-1974 grał w krakowskim Starym Teatrze, potem wyjechał do Warszawy a następnie do Paryża.

${ }^{28}$ Pszoniak 2018. 
Ta świadomość skróciła życie mojemu ojcu. Umarł z nostalgii. A umarł młodo, miał raptem 64 lata. Miał wprawdzie i inne, bardziej praktyczne powody - stracił pracę, kiedy nie chciał zapisać się do partii. Ale tak naprawdę, to nie mógł pogodzić się z utratą Lwowa. Mówił, że gdyby mógł, to wziąłby ręczny wózeczek i poszedłby tam piechotą ${ }^{29}$.

Małe dziecko pamięta obrazami. Pamiętam, jak musieliśmy w popłochu wyjechać ze Lwowa, bo ojciec nie chciał przyjąć obywatelstwa sowieckiego. Jakąś ciężarówką dowieźli nas do stacji. Pamiętam, jak pakowano na ciężarówkę obrazy, dywany... Bracia, dużo starsi ode mnie, usiedli na górze, a ja z szoferki, gdzie siedziałem z mamą, widziałem, że wszystko to, co zapakowaliśmy, spadało na nich. Mam jeszcze inny obrazek z dzieciństwa, pamiętam taką cofniętą od ulicy kamienicę, w której mieszkaliśmy i z której wyjeżdżaliśmy ${ }^{30}$.

Lwowianie osiedlali się w różnych miejscowościach w Polsce ${ }^{31}$, np. rodzina męża uległa rozproszeniu, zamieszkali w Jarosławiu, Krakowie, Warszawie, Bytomiu, Gliwicach, Opolu. Dziadkowie Polatyńscy stracili lwowskie mieszkanie, gdy pod koniec wojny wprowadził się do nich radziecki major z żoną. Na swój sposób pomógł dotychczasowym lokatorom, albowiem zadbał o ich transport do Polski i zezwolił zabrać niektóre rodzinne pamiątki.

Stan, w jakim znaleźli się wygnańcy Zagajewski nazwał bezdomnością: „Stałem się notorycznie bezdomny" ${ }^{32}$, Pszoniak - brakiem przynależności do konkretnego miasta: „Nie miałem swojego miasta” ${ }^{33}$. Obaj poszukiwali swojego miejsca, które mogliby nazwać domem, dopiero po wielu próbach ${ }^{34}$ znaleźli taką przystań - Zagajewski w Krakowie: „Lubię Kraków za to, że to jest - no takie moje miejsce na ziemi w tej chwili. Nie ma żadnej konkurencji właściwie”35, Pszoniak w Paryżu: „Jestem paryżaninem, mieszkam tam od 40 lat. W Paryżu mam swoje kąty, swoje ulubione ulice. To wyjątkowe, moje ukochane miasto"36.

$\mathrm{Na}$ moją prośbę spisała swoje wspomnienia kuzynka męża, Marta Lisowska ${ }^{37}$, lwowianka z pochodzenia, pieczołowicie chroniąca historię rodziny:

${ }^{29}$ Pszoniak 2011.

${ }^{30}$ Malatyńska 2016.

${ }^{31}$ Istnieje powszechne przekonanie, że największe po wojnie skupisko lwowian powstało we Wrocławiu, (ostatecznie opuszczonym przez rdzennych mieszkańców w 1946 r.), gdy faktycznie stanowili oni zaledwie 10\% jego ludności - Ther 2005.

32 Zagajewski 2007, s. 8.

${ }^{33}$ Pszoniak 2018.

${ }^{34}$ Zagajewski 2002, s. 9: „Ze Lwowa do Gliwic, z Gliwic do Krakowa, z Krakowa do Berlina (na dwa lata), potem Paryż, na długo i stamtąd co roku na cztery miesiące do Houston; powrót do Krakowa w 2002”. Pszoniak 2018: „Pochodzę ze Lwowa, zostaliśmy w czasie II wojny wysiedleni (...). Zamieszkaliśmy w Gliwicach, potem były studia w Krakowie, Warszawa. W Paryżu mam (...)”.

${ }_{35}$ Widok Krakowa/View of Krakow 2013.

${ }^{36}$ Pszoniak 2018.

${ }^{37}$ Marta Lisowska, z domu Heil, urodzona w Bytomiu w 1950 roku, od 1980 na emigracji w Walii, tam zmarła w 2019. 
Moja mama, Zofia Heilowa, bardzo przė̇yła wypędzenie ze Lwowa. Pierwsze dwa lata tułaczki w Krakowie i poszukiwanie „stałego” miejsca ograniczało się do tego, aby nie za daleko odjechać od granicy wschodniej, bo przecież będziemy wracać. Potem przenieśli się rodzice do Bytomia. W mieszkaniu 2,5-pokojowym mieszkało 11-12 osób. (...) wtedy moja mama zachorowała nie wiadomo na co. Nawet była w szpitalu. Dziś powiedziało by się, że to depresja ${ }^{38}$.

Wielu osiadłych w Krakowie lwowian po prostu nie rozpakowało swoich rzeczy, pielęgnując irracjonalne marzenie powrotu do domu, którego już nie było. Nie dotyczyło to wyłącznie starszego pokolenia - co byłoby bardziej zrozumiałe - ale i aktywnych zawodowo czterdziesto- czy pięćdziesięciolatków. Jedną z takich osób była babcia mego męża, wykształcona księgowa pracująca w krakowskim biurze Kolei Państwowych ${ }^{39}$, innymi -zaprzyjaźniony z teściami lekarz, później dziekan Wydziału Lekarskiego i rektor Akademii Medycznej w Krakowie ${ }^{40}$, także skrzypaczka ucząca w krakowskim Liceum Muzycznym, którą zapamiętała jedna z uczennic:

(...) kiedy byłam jeszcze uczennicą w Liceum Muzycznym w latach 60. (...) poznałam panią prof. Marię Truś, u której dokształcałam się w zakresie gry na skrzypcach. Pani profesor pochodziła ze Lwowa. Uczyła w konserwatorium gry na skrzypcach. Była świetną skrzypaczką i wspaniałym pedagogiem. Związana była z teatrem lwowskim, który najpierw ewakuował się do Szczecina. Mieszkała w Krakowie przy ulicy Krowoderskiej 41. Miała tylko pokoik bez łazienki. We Lwowie mieszkała przy ulicy Piekarskiej. Miała ogromne czteropokojowe mieszkanie, a w nim cenne obrazy i antyczne meble - co się z nimi stało? Udzielała lekcji i korepetycji na skrzypcach, dorabiała sobie do jakiejś nędznej renty. Pamiętam ją doskonale, wytworna starsza dama, która po wojnie cały czas żyła na walizkach, w spartańskich, prowizorycznych warunkach. Nie wiem, dlaczego tak, czy nie potrafiła już inaczej, czy czekała na kolejną przeprowadzkę?+11

Niektórzy wegetowali, uciekając od rzeczywistości w świat wyobraźni. W kręgu znajomych rodziny mego męża był znany lwowski antykwariusz. Mieszkał w Krakowie w małym pokoju wypełnionym po sufit cennymi książkami. Czytał je nocami, przenosząc się w dawne czasy. Lwów przywoływał przy każdej okazji i snuł o nim zajmujące opowieści. Sukcesywna wyprzedaż pamiątek wystarczała mu na bardzo skromną egzystencję ${ }^{42}$.

\footnotetext{
${ }^{38}$ RGW mat. własne.

${ }^{39}$ Wanda z Niżankowskich Polatyńska (1897-1983), urodzona w Hnilczu, k. Halicza. We Lwowie mieszkała od 1916 roku. Po 1945 osiadła w Krakowie.

${ }^{40}$ RGW mat. własne.

${ }^{41}$ Paluch 2006.

${ }^{42}$ RGW mat. własne.
} 
Wyobrażeniowe podróże do rodzinnych stron zastępowały te rzeczywiste, które $\mathrm{w}$ ówczesnych warunkach politycznych były niemożliwe. Rodzice męża ponownie zobaczyli nocny Lwów z okien pociągu, gdy w 1965 roku jechali na wczasy do Bułgarii, lecz wysiąśc z niego nie mogli. Łamiącym się głosem przywoływali autobiograficzne miejsca pamięci, łzy płynęły po policzkach, a wewnątrz przedziału milcząco przeżywał ten dramat nostalgii ich nastoletni syn. Gdy kilka lat później po raz drugi przejeżdżali przez Lwów zdążyli tylko wybiec przed dworcowy budynek, by „choć stanąć na lwowskiej ulicy”43. Nielegalnie opuścił pociąg relacji Przemyśl - Kijów Kazimierz Wiech, który w 1976 roku po raz pierwszy odwiedził miasto, poniekąd czyniąc zadość ojcowskiej tęsknocie:

Mogłem wtedy, ale tylko przez kilka godzin, wędrować po tym mieście, nie znając go zupełnie, pamiętając tylko kilka widoków ze zdjęć, które zachowały się w domu rodziców. Ojciec, kiedy wybierałem się w tę podróż, powiedział: „Jeśli tylko uda ci się być we Lwowie, przejdź się Wałami Hetmańskimi, idź do Katedry, bo na pewno będzie otwarta”. To było dla mnie wyzwanie, polecenie, jakie mi ojciec zostawił. Spełniam je do dzisiaj, bo przecież ojciec już dawno zmarł. Urodził się we Lwowie i bardzo za tym miastem tęsknił. Lwowskie korzenie mojej rodziny są bardzo głębokie. (...) Prapradziadkowie, prababcia i babcia, a także krótko mój ojciec mieszkali przy ul. Sodowej. Odwiedziłem kiedyś to miejsce, podobnie jak mój ojciec, który, kiedy po latach w końcu można było pojechać do Lwowa, pierwsze kroki skierował na ul. Sodową. Rodzina, która zamieszkiwała w mieszkaniu pradziadków i dziadków, przyjęła go bardzo serdecznie ${ }^{44}$.

Dla wielu lwowian utrata miasta była tak drastycznym doznaniem, że nigdy nie zdecydowali się na wyjazd, nawet gdy było to możliwe. Bogusław Schaeffer ujawnił kiedyś, że

gdziekolwiek jest, śni o Lwowie, mieście, w którym już nigdy się nie obudzi. Lwów żyje w nim i dlatego odwiedzi to miasto (Jeśli Bóg pozwoli) dopiero wtedy, gdy zapomni to wszystko, o czym dziś tak żywo pamięta... ${ }^{45}$.

${ }^{43}$ RGW mat. własne.

${ }^{44}$ Paluch 2013. Kazimierz Wiech, urodzony w 1950 roku w Krakowie w rodzinie zakorzenionej we Lwowie oraz w Kowlu na Wołyniu, absolwent i prof. dr hab. Uniwersytetu Rolniczego w Krakowie im. Hugona Kołłątaja, specjalista z zakresu ochrony roślin, wielokrotny stypendysta uniwersytetów w USA i Wielkiej Brytanii.

${ }^{45}$ Paluch 1997. Bogusław Schaeffer, kompozytor i teoretyk muzyki, krytyk muzyczny, dramaturg, grafik i pedagog, autor szeregu monografii i artykułów poświęconych muzyce współczesnej i historii muzyki. Urodzony w 1929 roku we Lwowie, w 1939 wywieziony do Kazachstanu. Po zakończeniu wojny najpierw w Opolu, potem w Krakowie. W 1986 roku został profesorem Mozarteum w Salzburgu, gdzie spędził 16 lat, i w końcu wybrał to miasto na miejsce stałych pobytów na zmianę z krakowską Nową Hutą. Zmarł w Salzburgu w 2019 r. 
Stanisław Lem, już jako popularny pisarz, wielokrotnie bywał w Związku Radzieckim, lecz nie we Lwowie:

Potem, w latach późniejszych, jeździłem parę razy do Moskwy, Leningradu, Charkowa. Jak mi tam proponowano, żebym jechał do Lwowa, to odmawiałem, tłumacząc ludziom, którzy byli tym zdziwieni, że jak ktoś się kochał w jakiejś niewieściej, ożenił się z nią i żył z nią długo i szczęśliwie, a potem przychodzi ktoś obcy i ona już kocha tego innego i wychodzi za niego za mąż - to jaki sens dowiadywać się, jakie ma dzieci z tym innym i jak żyje. Wolę lepiej nie mieszać się i tam się nie pokazywać, aczkolwiek zawsze podkreślałem, że Lwów i cała okolica - to moja lokalna Ojczyzna ${ }^{46}$.

Podobnie ojciec Adama Zagajewskiego wcale nie zamierzał tam pojechać:

Mój ojciec, dla którego Lwów był przez wiele lat jedynym miejscem i jedynym obrazem świata - tam się urodził i tam spędził młodość - systematycznie odmawia wyjazdu do tego miasta. Gdy jednak zaraz po powrocie z Ukrainy ja, który we Lwowie co prawda urodziłem się, ale nigdy nie zdążyłem go dobrze zobaczyć, pokazałem ojcu świeżo wywołane fotografie, natychmiast rozpoznał i nazwał każdą ulicę, każdy zaułek, nieomal każdą kamienicę po 56-u latach nieobecnościl!

Nie sądzę, choć trudno tu o statystyczne wyliczenia, by dystans do odwiedzin rodzinnego miasta był silniejszy w pokoleniu rodowitych lwowian, niejednokrotnie bowiem, choć w różnym stopniu, dotknął też spadkobierców rodzinnej traumy. Parę miesięcy temu rozmawiałam z moją koleżanką Basią. Jej ojciec, Zbigniew König, we Lwowie spędził kilka lat, najpierw ucząc się i potem w czasie wojny, gdy bezpowrotnie musiał opuścić rodzinny Kałusz. Wrósł w Kraków, jednocześnie żywiąc duży sentyment do Lwowa i do Kresów, ale nie chciał tam pojechać, gdyż nie chciał oglądać Lwowa zmienionego. Basia też nie pojechała: „Jakoś tak się nie składało" - cicho odpowiedziała na moje pytanie. Mój mąż długo nie mógł zdecydować się na konfrontację wyobrażeniowego obrazu miasta ze współczesną rzeczywistością. W czasie pierwszej wizyty bezskutecznie szukaliśmy parterowego domku Węcławowiczów na tzw. Zniesieniu, dopiero następnym razem odnalazł się gdzie indziej, na ulicy Jasnej. Za to na ul. Opata Hoffmana mąż rozpoznał kamienicę, gdzie na pierwszym piętrze było mieszkanie rodzinne jego mamy. Oglądaliśmy je z przeciwległej strony ulicy, w uchylonych drzwiach balkonu narożnego pokoju powiewała firanka, na parapecie widać było kwitnące rośliny. Każda

46 Tuzow-Lubański 1996.

${ }^{47}$ Zagajewski 2001 - esej napisany po pobycie we Lwowie w 2001 roku, gdzie uczestniczył w International Conference: Ukraine, Poland And The EU-Enlargement To The East, Lviv - Przemysl May 22-25, 2001. 
wizyta, nie tylko pierwsza, wywoływała falę emocji na szlakach rodzinnych wspomnień. Kiedyś zapytałam, jak postrzega miasta, z którymi rodzinnie jest związany; odpowiedział: „Lwów - Arkadia wyobrażeń dzieciństwa, ale zarazem to stałe wzruszenia i smutne wspomnienia rodzinne. Wolę jechać do Wilna, tam nie płaczę. Krakowa nie lubię!"48. Janusz Majewski miał czternaście lat, gdy w 1944 roku rodzina wyemigrowała do Krakowa. Wychowany w codzienności rodzinnego miasta, jako że: „Rodzice niemal codziennie rozmawiali o Lwowie, regułą były takie rozmowy przy stole" on przez wiele lat zachowywał dystans do całego bagażu przeszłości. Mówił: „Nie miałem sentymentu lwowskiego". Nawet wtedy, gdy pojechał na rekonesans, przygotowując się do realizacji filmu Sprawa Gorgonowej, gdyż - jak się wyraził: „Lwów był dotknięty hordami ze wschodu”. Nostalgia dogoniła go w najmniej oczekiwanym momencie i już w bardzo dorosłym życiu:

Sentyment wywołał amatorski zespół z Lublina nieumiejętnie naśladujący batak. W Sali Kongresowej był koncert poświęcony Kresom, poszedłem tam z ciekawości (...). Lwów to raj dzieciństwa, $\mathrm{z}$ biegiem lat wszystko, co dawne, pięknieje ${ }^{49}$.

Wojciech Pszoniak Majewskiemu zawdzięcza wyjazd do Lwowa w 2016 roku na prezentację filmu Ekscentrycy, w którym grał jedną z ról. Wcześniej nie chciał tam wracać. W 2011 roku, udzielając wywiadu dziennikarzowi „Tygodnika Powszechnego”, kategorycznie zastrzegł:

Do fizycznego, realnego Lwowa nigdy nie pojechałem i nie pojadę. On już nie ma nic wspólnego z moją rzeczywistością. Wszyscy, którzy zobaczyli Lwów, są zachwyceni. Ale Tadeusz Różewicz mi kiedyś powiedział: „Co ty mówisz o tym Lwowie? To są już tylko mury. Ludzie tworzą miasto”. Mam albumy, mam piękną starą mapę Lwowa, którą dostałem niedawno. Jest na niej widoczna fabryka Baczewskiego. Matka mi opowiadała, że kiedy wybuchła I wojna, kule trafiały w cysterny, z których lał się spirytus. Ludzie podbiegali i nalewali go sobie do wiader. Mam więc pod powiekami swój film o Lwowie, który podświadomie czasem sobie puszczam ${ }^{50}$.

A jednak kilka lat później zdecydował się i jak wielu innych dziedziców nostalgii przemierzył rodzinne ścieżki:

\footnotetext{
${ }^{48} \mathrm{~W}$ Wilnie i szerzej - na Litwie rodzinna genealogia męża osadzona jest znacznie wcześniej - RGW mat. własne.

${ }^{49}$ Majewski 2017. Janusz Majewski urodził się we Lwowie w 1931 roku. Po wojnie mieszkał w Krakowie. Absolwent architektury Politechniki Krakowskiej i reżyserii Państwowej Wyższej Szkoły Filmowej w Łodzi, reżyser filmowy, dramatopisarz, pisarz, scenarzysta, wykładowca.

${ }^{50}$ Pszoniak 2011.
} 
Odwiedziłem Park Stryjski, gdzie moja mama chodziła z wózeczkiem, mam zdjęcia. Byłem, odwiedziłem. Lwów jest nieruszony wojną, więc ta tkanka jest ta sama. To miasto jest dalej takie, jakie było: Hotel George, tylko to już nie jest ta klasa, do którego chodzili moi rodzice, Teatr Lwowski - odwiedziłem te miejsca, które znam z opowiadañ ${ }^{51}$.

Ulicę, na której mieszkaliśmy, miejsce, w którym ojciec miał budować dom, ale wybuchła wojna. Zobaczyłem Operę Lwowską, gdzie mój dziadek, który był chemikiem i dyrektorem w słynnej fabryce wódek Baczewskiego, miał swoją lożę $e^{52}$.

Natomiast współczesnym stanem miasta jest rozgoryczony:

Miasto ważne dla nas, mityczne, nie jest na szczęście bardzo zniszczone, ale wszystko jest w nim takie „spsiałe”. Jest straszny dysonans między historią tego miejsca, a ludźmi, którzy dziś chodzą tam po ulicy ${ }^{53}$.

Kilka lat temu rozmawiałam z trzydziestolatkiem, Jackiem W., który wrócił po dwuletnich studiach artystycznych na lwowskiej uczelni. Rodzice są krakowianami o kresowej, w tym lwowsko-wileńskiej genealogii. Nie znał swoich dziadków zamieszkałych po wojnie w Krakowie, bo urodził się wiele lat po ich śmierci. W Krakowie skończył architekturę, a do Lwowa pojechał, bo chciał poszerzyć swoje zawodowe wykształcenie i szybko nauczył się ukraińskiego. Jak stwierdził, nie kierował się wtedy żadnymi rodzinnymi sentymentami. A jednak wędrował po Lwowie i po współczesnej Ukrainie śladami przodków. Przywiózł nawet okruch ceramiki znaleziony w zaroślach porastających przypuszczalne miejsce nieistniejącego już dworku, o którym mówi rodzinna tradycja. A całkiem niedawno oświadczył, że chętnie przeniósłby się do Lwowa, by tam po prostu żyćs

W pięknym eseju Powracajacy do domu Alfred Schütz powiada, i nie sposób się z nim nie zgodzić, że dom ma różne znaczenia dla różnych ludzi i kryją się one w stwierdzeniach „mój budynek mieszkalny”, „,mój pokój”, „mój ogród”, „,moje miasto”. To dom rodzinny, język ojczysty, krewni, najbliżsi sercu, przyjaciele. Kojarzy się z ulubionym pejzażem, piosenkami, których uczyła matka, tymi jedynymi potrawami, codziennymi przedmiotami, zwyczajami, indywidualnymi nawykami. Zatem dom oznacza szczególny sposób życia, na który składają się ważne i drobne komponenty pielęgnowane przez człowieka i wywołujące określone emocje ${ }^{55}$. Dla wielu lwowian nowe miejsce zamieszkania - Kraków z historycznym splendorem matecznika polskości - nie stało się domem, mimo że wartości kultury narodowej były im bardzo bliskie. Przede wszystkim nie

\footnotetext{
${ }^{51}$ Pszoniak 2018.

${ }^{52}$ Pszoniak 2018.

${ }^{53}$ Pszoniak 2018.

${ }^{54}$ RGW mat. własne.

55 Schütz 2012, s. 204.
} 
był Lwowem, który pozostał ich miejscem na ziemi mocno zakorzenionym w pamięci pierwszego pokolenia imigrantów i przekazanym dzieciom oraz wnukom wychowanym już w nowym miejscu. Idealizacja rodzinnego miasta prowadziła do konkurencyjności względem Krakowa. Do Lwowa wracano w rozmowach, w marzeniach, w snach i porównywano z Krakowem. Ową stałą obecność trafnie uchwycił Paweł Pencakowski, krakowski potomek lwowian:

Choć bowiem całe życie mieszkałem w Krakowie, to jednak ten Lwów był wciąż obecny w moim rodzinnym domu. (...) Był ten Lwów punktem odniesienia wszelkich ocen, funkcjonował we wszystkich możliwych porównaniach i zawsze, na każdym polu wygrywał: ta co tam Rzym, co Paryż i Florencja - Lwów to dopiero! ${ }^{56}$

Rodzinne posiady w rzeczywistym Krakowie, ale z wizją Lwowa ciągle nienależącego do czasu bezpowrotnie przeszłego, przywołał Kazimierz Wiech:

(...) W latach 50. każdy pretekst był dobry, żeby się spotkać w gronie rodziny. Pamiętam śpiewny akcent lwowski, jaki słyszałem podczas ich rozmów. Ciągle wracali pamięcią do Lwowa: jak tam jest na Sodowej, jak tam w kościele u Marii Magdaleny, a jak na Akademickiej... Wciąż powtarzali, dobrze byłoby pojechać, dobrze byłoby wrócić (...). Już wtedy docierało do mnie, że była jakaś cezura czasowa. Skończyło się to piękne życie, opisywane w takich zupełnie niedoścignionych barwach. Jak oni się potrafili rozwodzić o tym, jak wyglądała choinka? I choć obok stała bajecznie ubrana i rozświetlona jodełka, to gdzie jej tam było do tej z Kowla czy ze Lwowa! ${ }^{57}$

Andrzej Chlipalski znów snuje barwną opowieść o kontaktach towarzyskich w krakowskim gronie kresowian. Na lekcje angielskiego trafił do pani Adeli Duninowej ze Lwowa, która mieszkała z siostrzenicą Wisią w ponurych izdebkach na dole gmachu Muzeum Czartoryskich, na rogu ulic Pijarskiej i św. Jana. Pani Adzia Duninowa była ziemianką zza Zbrucza. Świetnie znała kilka języków i uczyła ich. Pani Wisia, czyli Jadwiga Horodyska, znakomita rzeźbiarka, przygotowywała pyszne kolacje, na które „przychodziło coraz więcej osób, głównie z wyższych sfer, w większości z naszych, wschodnich stron"58. Takie kameralne spotkania odbywały się niemal w każdym domu „lwowskich krakowian”, okolicznościowe czy spontaniczne. Przychodzili zaprzyjaźnieni

${ }^{56}$ Pencakowski 2006, s. 23. Paweł Pencakowski, urodzony w Krakowie w lwowskiej rodzinie, historyk sztuki, profesor Akademii Sztuk Pięknych im. Jana Matejki w Krakowie, członek Społecznego Komitetu Odnowy Zabytków Krakowa.

${ }^{57}$ Paluch 2013.

${ }^{58}$ Paluch 2017. Andrzej Chlipalski, urodzony w 1931 r. we Lwowie, w Krakowie od 1944 roku. Absolwent architektury Politechniki Krakowskiej, w latach 1954-1996 zaprojektował i zrealizował liczne obiekty budownictwa służby zdrowia. Od roku 1989 wiceprezes, obecnie prezes Oddziału Krakowskiego 
lwowianie, w towarzystwie innych znajomych i swoich krewnych, a powracającym tematem rozmów był Lwów i Kresy. Zatem nostalgia uruchomiła proces budowania wspólnoty wyobrażonej (w rozumieniu nadanym przez B. Anderson ${ }^{59}$ ), która do 1989 roku tworzyła się wyłącznie poprzez kontakty prywatne, „domowe”, dopiero potem została ujęta w ramy oficjalnie działających instytucji - Krakowskiego Oddziału Towarzystwa

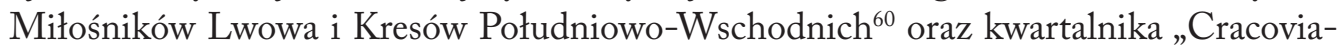
-Leopolis" ${ }^{61}$.

W przekazach powstających z okruchów pamięci tamten Lwów pozostał miastem idealnym, a jego mentalna mapa była niczym nieograniczona, zapisywano na niej miejsca, zdarzenia rzeczywiste i zasłyszane, przeżycia, doznania estetyczne, dźwięki, zapachy. Babcia mojego męża $\mathrm{z}$ rozrzewnieniem przypominała modlitewną ciszę $\mathrm{w}$ ulubionym kościele św. Elżbiety, wuj, architekt, bardzo sugestywnie opisywał niezwykłość strzelistego wnętrza lwowskiej katedry. Ktoś inny zapamiętał smak kawy i plotkarską atmosferę kawiarni w najpiękniejszym na świecie pasażu handlowym Mikulasza. A chyba najwięcej wspomnień skupiły gwarne, tętniące życiem ulice: Łyczakowska, Wały Hetmańskie, Akademicka. Pamięć osadzona była w miejskiej przestrzeni, w sensualnym i emocyjnym jej przeżywaniu. Opowiada Zdzisław Żygulski jr.:

Jaki w mojej pamięci pozostał Lwów przedwojenny w porównaniu z Krakowem, a także z Warszawą? (...) to miasto wyróżniał nieodparty urok, nieporównywalny z niczym, niewidoczny na starych austriackich pocztówkach, żyjący jedynie na kartach wspomnień, w poezji i piosence. Był to osobliwy splot natury, secesyjnych kamienic, mieszkańców i ich zawiłej historii. (...) Nie miał Lwów wielkiej rzeki - Pełtew, na miarę krakowskiej Rudawy, płynęła już podziemnymi kanałami, ale były świetne kąpieliska (...) Zimy bywały mroźne, śnieżne, rozdzwonione dwukonnymi sankami, roztańczone ślizgawką na Pełczynie. Miał Lwów wspaniałą krystaliczną wodę (...), wyborny chleb (...) miał precle moczone w piwie przed upieczeniem, z solą lub makiem, znacznie górujące nad dzisiejszymi krakowskimi obwarzankami, miał wreszcie najwspanialsze na świecie ciastka, czekoladki i marcepany arcymistrza cukierniczego pana Ludwika Zalewskiego. Lwowiacy byli ludźmi serdecznymi i towarzyskimi. Wieczorami trwał nieustanny spacer w tę i tamtą stronę ulicy Akademickiej, po lwowskim korso chodzono szeregami, trzymając się za ręce. W soboty i niedziele nieprzerwane korowody ciągnęły do Parku Stryjskiego i na Plac Powystawowy (z corocznymi jesiennymi Targami Wschodnimi), gdzie biesiadowano w niezliczonych knajpkach przy lwowskim piwie i przepysznych parówkach z musztardą. Tę wspólnotę lwowiaków, bez

Towarzystwa Miłośników Lwowa i Kresów Południowo-Wschodnich oraz członek Zarządu Głównego, redaktor naczelny kwartalnika „Cracovia Leopolis”.

${ }^{59}$ Anderson 1991, s. 19.

${ }^{60}$ Istnieje od 1989 r. i jest jednym z kilkudziesięciu kilku działających obecnie w Polsce oddziałów Towarzystwa Miłośników Lwowa i Kresów Południowo-Wschodnich, powstałego we Wrocławiu w 1988 r.

${ }^{61}$ Kwartalnik poświęcony polskiemu dziedzictwu historii i kultury Lwowa i Małopolski Wschodniej oraz ludziom związanym w przeszłości i współczesności z tamtymi ziemiami. Ukazuje się od 1995 roku. 
względu na pochodzenie i stan, łączył humor i beztroska wesołość, często ujęte w piosence, w specyficznej lwowskiej gwarze, mieszającej słowa polskie, niemieckie, ukraińskie i żydowskie, a nawet ormiańskie, tureckie i greckie, jak w owym słowie majcher, czyli nóż, z greckiego - machaira ${ }^{62}$.

Wtóruje mu Bogusław Schaeffer, przeciwstawiając rodzinne miasto wszystkim innym:

A poza tym Lwów - owo „wesołe miasto” - tak niegdyś źle potraktowane przez Roda-Rodę $e^{63}$, miasto żywe (dzisiejsze miasta - to trupiarnie), energiczne, zapełnione najprzeróżniejszymi typami od wielkich logików i matematyków aż po najgorsze typki batiarskie, które nigdy innych „dołów społecznych” w niczym nie przypominały (mój Boże, dzisiejsze szumowiny, które pną się nawet po laury polityczne!), miasto wielu narodowości i wyznań, czy może być dla dramaturga coś bardziej barwnego! ${ }^{64}$

Mityzacja rodzinnego miasta nie zaskakuje, to oczywista prawidłowość kulturowa, warto natomiast rozważyć stosunkowo nikłą obecność Lwowa w Krakowie. Inaczej niż we Wrocławiu, gdzie lwowianie „(...) dali się słyszeć i na ulicach, i w uniwersyteckich salach, i w instytucjach kulturalnych (...). Oni też podtrzymywali mit Lwowa, w murach Wrocławia nucili lwowskie piosenki, piekli chleb w lwowskich piekarniach, strzygli się we lwowskich fryzjerniach, odwiedzali lwowskie jadłodajnie" ${ }^{65}$.W Krakowie ich pamięć była skrywana, istniała sama dla siebie, niezależnie od krakowskiej. Kilkanaście lat chodziłam do tej samej szkoły, podstawowej i liceum, z moim przyszłym mężem (z nim byłam nawet w jednej klasie) i z jego dwiema siostrami, nic nie wiedząc o ich lwowskiej genealogii. Oni z tamtych lat zapamiętali „strach rodziców, by nie przyznawać się do Lwowa" ${ }^{66}$ oraz funkcjonowanie w dwóch odrębnych światach - wewnętrznym rodzinno-towarzyskim lwowskim i zewnętrznym krakowskim. W moich czasach licealnych prywatnie uczyłam się angielskiego u dystyngowanej pani Beaty, wdowy po przedwojennym pułkowniku polskiego wojska. Dopiero na jej pogrzebie dowiedziałam się, że pochodziła ze Lwowa. Pamięć o utraconym mieście była w Krakowie pamięcią wyobcowaną. Nie da się tego wytłumaczyć li tylko cenzurowaniem tematyki kresowej w oficjalnym dyskursie epoki Polski Ludowej. Skądinąd przecież wiadomo, że paradoksalnie

${ }^{62}$ Żygulski 2003, s. 117-118. Zdzisław Żygulski jr., 1921-2015, dzieciństwo i młodość spędził we Lwowie, od 1945 r. mieszkał w Krakowie. Historyk sztuki, muzealnik, profesor nauk humanistycznych, wieloletni kustosz w Muzeum Czartoryskich w Krakowie i wykładowca w Akademii Sztuk Pięknych im. Jana Matejki w Krakowie.

${ }^{63}$ Aleksander Roda-Roda, właściwie Sandór Friedrich Rosenfeld, 1872-1945, pisarz, dramaturg, dziennikarz. Wiodącym tematem jego twórczości jest ironicznie przedstawiony świat c.k. monarchii austro-węgierskiej.

${ }^{64}$ Paluch 1997.

${ }^{65}$ Bednarek 1996, s. 95.

${ }^{66}$ RGW Mat. własne. 
spowodowało to silną mitologizację Kresów i miast kresowych w potocznej świadomości Polaków. We Wrocławiu pozbawionym polskich treści mit Lwowa zagnieździł się na dobre i miasto stało się spadkobiercą lwowskiej tradycji ${ }^{67}$. Tymczasem Kraków w latach powojennych zmagał się z procesem dewaluacji swego symbolicznego znaczenia, wprawdzie zakorzenionego $\mathrm{w}$ polskim uniwersum narodowym, ale podlegającego ideologicznym manipulacjom. Tę sytuację trafnie zdiagnozował Jacek Purchla, zwracając uwagę na wielorakie konsekwencje narzuconego przez aparat propagandowy PRL nowego wizerunku Krakowa jako „bastionu reakcji i oporu wobec nowej rzeczywistości”68. Paweł Kubicki dopowiedział o „pomijaniu miasta w kulturze masowej: literaturze, filmie, popularnych piosenkach. Kraków <znikał > z oficjalnej kultury masowej, a jeśli już się pojawiał, to jako symbol <dulszczyzny>(...)" 69 .

Różne są przeżycia lwowian przybyłych do Krakowa po wojnie, pozytywne i negatywne, niektórzy stronią od tego tematu. Niewiele miała do powiedzenia Irena Dziedzic, która wraz z matką spędziła tu kilka pierwszych lat po wyjeździe ze Lwowa. Zachowała do nich gorzko-ironiczny dystans ${ }^{70}$. W retrospekcjach lwowian, czy szerzej - kresowian, którzy doświadczyli traumy depolonizacji, Kraków nieprzyjemnie zaskakiwał. Pierwszy ogląd miasta podczas przejazdu furmanką z dworca kolejowego w Płaszowie na ulicę Krupniczą 22 zapamiętała profesor Maria Podraza-Kwiatkowska:

„(...) miasto robiło wrażenie niezwykłego, jakby jeszcze przedwojennego. Ludzie byli porządnie ubrani, dobrze odżywieni, a wśród nich my - jakby z innego świata. To było takie pierwsze, niezbyt przyjemne zetknięcie się z miastem" ${ }^{\text {"11 }}$.

W rodzinie Adama Zagajewskiego:

Była ciotka Berta, nauczycielka muzyki; po wojnie przeniosła się do Krakowa i mieszkała kątem u dalekich znajomych, którzy pozwalali jej rozkładać na noc łóżko w kuchni.W dzień za to nie wolno jej było przebywać w domu; wędrowała po mieście, czekając nadejścia wieczoru. Jedyny swój skarb, fortepian, zdeponowała w krakowskim konserwatorium, ponieważ nie mogła go nosić podczas niekończących się spacerów ulicami tego miasta ${ }^{72}$.

Z wielu relacji przebija niekorzystny dla krakowian wizerunek tych, „którzy z uprzedzeniami i chłodem, z moralnego przymusu, przyjmowali ekspatriantów... Powodowało to, że niektórzy kresowianie, jeśli tylko mogli i nadarzyła się im korzystna

${ }^{67}$ Suleja 2001; Eggers-Dymarski, Gizewska, Lenk, Pfeifer 2005; Thum 2005.

${ }^{68}$ Purchla 1996, s.126-127, 280

${ }^{69}$ Kubicki 2010, s. 118.

${ }^{70}$ Dziedzic 1992, s. 105, 240-241.

71 Zborek 2011. Prof. Maria Podraza-Kwiatkowska (1926-2016), wieloletnia wykładowczyni Uniwersytetu Jagiellońskiego, historyk literatury, eseistka, członkini Stowarzyszenia Pisarzy Polskich. Opuściła Lwów w 1945 roku i wspólnie z matką przeniosła się do Krakowa.

${ }^{72}$ Zagajewski 2007, s. 13. 
sytuacja, uciekali czym prędzej z Krakowa, najchętniej do Wrocławia..." - ocenia Janusz Paluch, propagator ochrony pamięci o Kresach, współzałożyciel kwartalnika „Cracovia-Leopolis”, na łamach którego opublikował wiele wywiadów z „lwowskimi krakowianami" ${ }^{\prime 3}$. Pustą przestrzeń powojennego Wrocławia wypełnili imigranci, natomiast w Krakowie zetknęli się z zasiedziałą społecznością, która z rezerwą odnosiła się do inności „mówiących przywiezionym ze wschodu językiem” - jak trafnie ujął Adam Zagajewski ${ }^{74}$.

Nie było łatwo, nie było łatwo. Miałam inny akcent. Zawsze mi się wydawało, że w Polsce lubią „Lwowską Falę”, a tutaj się zetknęłam - tak. Acha, mówię, ale jestem dla nich po prostu inna. Poszłam na lektorat wymowy, starałam się bardzo pięknie powiedzieć wiersz Pawlikowskiej i słyszę, jak pan prowadzący mówi: $Z$ takim lwowskim akcentem na lektorat wymowy Pani przyszła? Więc tak to różnie było - ciągnie swą opowieść prof. Maria Podraza-Kwiatkowska ${ }^{75}$.

We wspomnieniach powtarza się wątek postrzegania przyjezdnych jako obcych, nawet określania ich pogardliwym mianem o pejoratywnych konotacjach politycznych jako „Ruskich” bądź „Ukraińców”. Doświadczył tego między innymi poeta, Adam Macedoński, który jako kilkuletni chłopiec przyjechał ze Lwowa do Krakowa:

Tu w Krakowie nauczyłem się bić, bo miałem wyraźny akcent i mówili do mnie «ty, Ukrainiec!». Ja mam krew ruską, bo moja babka była Rusinką. Ale Ukraińcy są dla mnie czymś innym niż Rusini ${ }^{76}$.

Diaspora lwowska budowała obraz Krakowa przez ciąłłe porównania do Lwowa. Nawet wtedy, gdy Kraków został zaakceptowany, to poprzez Lwów i dzięki Lwowowi. Stefan Berdak, artysta malarz mieszkający na krakowskim Salwatorze, malowniczym osiedlu willowym z początku XX wieku, poddał się jego urodzie, bo zobaczył w nim rodzinny Lwów:

Tu jest pięknie niezależnie od pory roku i pogody. Zawsze świeci słońce. A przede wszystkim ten Salwator tak przypomina mi Lwów, te wszystkie chwile w mym życiu związane ze Lwowem... ${ }^{77}$.

${ }^{73}$ Paluch 2017.

${ }^{74}$ Cytat z wiersza Dżungla Adama Zagajewskiego.

75 Zborek 2011.

${ }^{76}$ Paluch 2007. Adam Macedoński, artysta plastyk, poeta, działacz opozycji demokratycznej w okresie PRL, urodzony w 1931 r. we Lwowie, w Krakowie mieszka od 1945 r.W 1992 r. odwiedził Lwów po raz pierwszy od wojny.

77 Paluch 2003. Stefan Berdak, 1927-2018, lwowianin. Po wysiedleniu zamieszkał w Krakowie, absolwent krakowskiej Akademii Sztuk Pięknych, malarz, rysownik, grafik, dziennikarz przez wiele lat związany 
W biograficznym wstępie do jednej z książek dla dzieci Tadeusza Śliwiaka ${ }^{78}$, córka poety naświetliła powojenne ojcowskie poszukiwania stałego miejsca zamieszkania:

(...) które by było chociaż trochę podobne do utraconego kraju dzieciństwa. I tak trafił do Krakowa. Okazało się, że to miasto bardzo przypomina przedwojenny Lwów - trudno się dziwić, oba miasta były przecież „perłami” Galicji. Odznaczały się też podobną atmosferą przesyconą sztuką i nauką. Tu Tadeuszowi łatwiej było oddychać - tu znalazł dom, miłość, skończył słynną krakowską Szkołę Teatralną i tutaj żył aż do tragicznej śmierci w grudniu 1994 roku. Bardzo kochał to „z wyboru swoje miasto"79.

Jednak na ogół Kraków przegrywał z idealizowanym miastem dzieciństwa i młodości, drażniła mała skala miasta, niespieszne tempo życia, prowincjonalizm krakowskiej zabudowy, celebrowanie dawnej stołecznej doniosłości i archaiczne zwyczaje. Dynamiczny, barwny, wielokulturowy Lwów przeciwstawiano statecznej tradycji Krakowa. Jerzy Madeyski, znany w Krakowie historyk sztuki i dziennikarz, lwowianin $\mathrm{z}$ urodzenia, tak widział oba miasta:

W porównaniu ze Lwowem Kraków spał, co prawda w niezwykle dostojny sposób. Ludzie snuli się po ulicach, konie ledwie człapały, a śmiechu i muzyki w ogóle w nim nie było. I tak pięknych zakątków, jak Stryjski Park czy Wysoki Zamek, ani tak wielkomiejskich arterii, jak Wały Hetmańskie, ani Racławickiej Panoramy, ani koni rozpędzonych w długim kłusie. Ani tego różnojęzycznego gwaru metropolii, ani śpiewnego akcentu, któregośmy się w tajemnicy przed starszymi uczyli. Całej tej - pozbawionej chamstwa - zadzierzystości, połączonej z serdecznością nie spotkałem w żadnym innym mieście i pewnie jej już nie spotkam ${ }^{80}$.

Rodzice mojego męża byli zszokowani, że w Uniwersytecie Jagiellońskim, w którym w 1946 roku podjęli studia przerwane we Lwowie, profesora wchodzącego na wykład woźny całował w rękę. Trzydzieści kilka lat później, kiedy mój mąż, świeżo wypromowany doktor historii sztuki wszedł do macierzystego instytutu, najstarszy z woźnych w Collegium Maius tak samo chciał go powitać ${ }^{81}$.

Różnice w stylu życia utrwalała wspólnota losów i wspomnień - nostalgia lwowska i szerzej, kresowa. Na poły realne, na poły metafizyczne zanurzenie w utraconej

$\mathrm{z}$ „Przekrojem”.

78 Tadeusz Śliwiak, poeta, autor literatury dziecięcej, dziennikarz, ur. 1928 we Lwowie. Po wysiedleniu krótko przebywał w Warszawie, po czym osiadł w Krakowie, gdzie mieszkał aż do śmierci w 1994.

79 Śliwiak 2018.

${ }^{80}$ Kościk 1999. Jerzy Madeyski, 1931-2005, lwowianin z urodzenia, od wojny w Krakowie, historyk sztuki, felietonista, scenarzysta i konsultant filmów dokumentalnych.

${ }^{81}$ RGW mat. własne. 
przestrzeni, dotychczas codziennej i swojskiej, a potem gwałtownie zawłaszczonej przez ideologię i politykę powodowało, że wykształciły się różne praktyki przetrwania, które spajały silne poczucie lwowskości obejmujące wiele sfer życia. W diasporze odżywały wszelkie dawne znajomości, wcześniej powierzchowne, mało znaczące. Teraz bliska była koleżanka z dawnego przedszkola, przypadkiem spotkana na krakowskiej ulicy, znajomy kolegi okazywał się tamtym panem przelotnie widywanym we lwowskim tramwaju. Paweł Pencakowski opowiadał:

Do mego świata należeli więc od samego początku honorowi batiarzy lwowscy, eleganckie lwowskie panie i rezolutne przekupki. Jedna z nich zamieszkała po wojnie w Krakowie i moja babcia robiła kawał drogi, aby - pod pozorem kupowania marchewki czy pietrusz$\mathrm{ki}$ - porozmawiać sobie $\mathrm{z}$ tą kobietą, znaną tylko z widzenia sprzed wojny. Spotkania pani profesorowej z przekupką kończyły się zazwyczaj łzami ${ }^{82}$.

Środowiskowej solidarności wielu zawdzięcza bardzo dużo, między innymi Adam Macedoński:

Jeszcze w Liceum Plastycznym, kiedy popadłem w konflikt z dyrekcją szkoły, moje lwowskie pochodzenie uratowało mnie przed wyrzuceniem. Wybronili mnie nauczyciele z Kresów, którzy tłumaczyli, że pochodzę ze Lwowa, że wciąż tęsknię i czekam na powrót do swego miasta... Cały czas Kresowiacy trzymali się razem, zresztą do tej pory wyraźnie dostrzec można różnice w kulturze Polaków miejscowych krakowskich i tych pochodzących z Kresów ${ }^{83}$.

Stefan Berdak zapamiętał przypadkowe spotkanie swego kolegi, Romana Cieślewicza $\mathrm{z}$ dawnym nauczycielem historii sztuki, profesorem Włodzimierzem Hodysem, który po przyjeździe ze Lwowa do Krakowa dyrektorował Państwowemu Liceum Sztuk Plastycznych. „Ten ze lwowska powiedział mu: Nu, ta ściągaj wszystkich lwowiaków! Ta niech przyjeżdżają do mnie! Długo się nie zastanawialiśmy. W Krakowie zostaliśmy bardzo serdecznie przyjęci przez rodzinę Hodysów ${ }^{84}$. Tutaj też obaj podjęli naukę w liceum plastycznym, po maturze - na Akademii Sztuk Pięknych.

Na początku lat 70. XX wieku Kazimierz Górski został trenerem polskiej kadry narodowej w piłce nożnej. Na wieść o tym środowisko „lwowskich krakowian” zapowiadało duży sukces. A kiedy polska drużyna w roku 1974 zdobyła srebrny medal w mistrzostwach świata, $z$ dumą przypisano to lwowskim umiejętnościom rodaka - trenera.

\footnotetext{
82 Pencakowski 2006, s. 23.

${ }^{83}$ Paluch 2007.

${ }^{84}$ Paluch 2003. Roman Cieślewicz, urodzony w 1930 roku we Lwowie, zmarł w 1996 w Paryżu, artysta grafik, jeden z głównych twórców „polskiej szkoły plakatu”, studiował w Krakowie, potem przeniósł się do Warszawy, następnie pracował w Zachodnich Niemczech, we Włoszech, w 1963 osiadł w Paryżu.
} 
Wspomniany lwowski antykwariusz leczył wszelkie choroby u znajomego ze Lwowa ginekologa. Dopiero gdy w środowisku lwowskim poznał mego teścia, chirurga, przeszedł do niego. Kiedy siostry męża przedstawiały rodzicom swoich narzeczonych, ten $\mathrm{z}$ rodziny o korzeniach lwowskich został od razu zaakceptowany, drugi natomiast, z rodowodem nie „stamtąd”, był traktowany życzliwie, ale z uprzejmym dystansem przeszło rok $^{85}$.

Znajoma rodziców męża nie mogła im wybaczyć, że zatracili charakterystyczną śpiewną lwowską wymowę, nie zauważając, że jej syn złapał krakowski akcent. Jako środowiskowy znak rozpoznawczy funkcjonowały zdrobnienia imion - Rysia od Marii, Mundzio od Zygmunta, Renia od Teresy, Kaju od Kazimierza. Zdaniem lwowian wydawały się krakowianom nieco osobliwe. Specyficzne lwowskie słownictwo i obyczajowość były cechą świadomie pielęgnowaną i jeszcze dziś wyróżniają osoby pochodzące $z$ tych rodzin nawet w trzecim pokoleniu. Doświadczam tego na co dzień, kiedy gotuję mleko, to moje „kipi z rondelka” a mleko męża „wybiega z ryneczki”, on „zapala” a ja „podświecam gaz”, on jada ser $\mathrm{z}$,trembulką” ja zaś z „młodą cebulką”, jego dziadek nosił żółte „meszty”, mój - brązowe „buty”, jego babcia piekła „makownik” i „sernik” w „bratrurze”, moja w „szabaśniku” ,makowiec” i „serowiec” (a czy dzisiaj obie by piekły w piekarniku?). $\mathrm{Na}$ Wielkanoc on dzieli się jajkiem podczas niedzielnego śniadania i wędlinę zakąsza kawałkiem babki, ja dzielę się już w Wielką Sobotę po poświęceniu koszyczka, a babkę jem na deser. Ja mam pisanki malowane, on „brokatowe” - oklejane skrawkami ozdobnych materiałów. W Boże Narodzenie on wiesza bombki na choince a ja bańki na drzewku, ale obojgu nam prezenty na Gwiazdkę zawsze przynosi Aniołek i wigilijną kolację kończymy strudlem ${ }^{86}$.

Moje wyprawy do Lwowa, te realne i te pośrednie poprzez wysłuchane bądź przeczytane relacje, okazały się etnologiczną podróżą do wspólnoty pamięci lwowian, dla których ów świat nie zaniknął, i niczym Paryż Hemingway’a - nigdy nie ma końca. Parafrazując błyskotliwe słowa pisarza odniesione do francuskiej stolicy, można za nim rzec: „Jeżeli miałeś szczęście mieszkać we Lwowie jako młody człowiek, to dokąakolwiek się udasz przez resztę życia, idzie on za tobą, bo Lwów jest świętem ruchomym”. W wierszu Jechać do Lwowa, dedykowanym rodzicom, Adam Zagajewski powiada: „Lwów jest wszędzie". Metafora miasta jako święta ruchomego wymaga uzupełnienia. Wsparte na emocjach nostalgiczne powroty są udziałem także tych, którzy we Lwowie wcześniej nie mieszkali i podróżują do miasta odziedziczonej wyobraźni. Tkwi ona $\mathrm{w}$ następnych pokoleniach, które ze wzruszeniem wędrują prywatnymi śladami rodziny, bądź zanurzeni w narodowej wspólnocie postpamięci - ścieżkami historycznych skojarzeń, a miejsce/Lwów doświadczane nakłada się na miejsce/Lwów wyobrażone ${ }^{87}$.

\footnotetext{
${ }^{85}$ RGW mat. własne.

${ }^{86}$ RGW mat. własne.

${ }^{87}$ Chodzi o miejsce antropologiczne w rozumieniu Marca Augé.
} 
Zdaniem Swietłany Boym dwa rodzaje nostalgii charakteryzują stosunek do przeszłości - restytucyjny i refleksyjny. Nostalgia restytucyjna (odtwórcza) zwrócona jest ku przeszłości, ku czasowi minionemu, który próbuje powstrzymać i często przekształca w mityczny dom. Ma wymiar utopijny. Skupia się na tradycji, wysoko ją wartościuje $\mathrm{w}$ obawie przed utratą pamięci. Refleksyjna koncentruje się na przeżywaniu tęsknoty jako takiej, obraz przeszłości jest złożony, a jej przeżywanie kontemplacyjne. Nostalgia refleksyjna jest bardziej związana $\mathrm{z}$ czasem historycznym i indywidualnym, z nieodwołalnością przeszłości i ludzkiej skończoności. Refleksja sugeruje elastyczność w medytacji nad historią i upływem czasu ${ }^{88}$.

Ma rację Swietłana Boym, gdy mówi, że oba typy nostalgii nie wykluczają się wzajemnie, ale niesłusznie - moim zdaniem - silnie eksponuje różnice, które mniej lub bardziej przekonująco tropi w sposobach narracji. $Z$ mojego etnologicznego rekonesansu wynika, że oba sposoby narracji o przeszłości przenikają się wzajemnie nawet w jednej biografii, nawet w jednej wypowiedzi. Jak zatem w pamięci o Lwowie odróżnić nostalgiczną tęsknotę (refleksja) od nostalgicznego mitu (restytucja)? Obie są przeżywane przez migrantów w pierwszym, drugim, nawet w trzecim pokoleniu, nadto - obecne nie tylko w rodzinnej, lecz także w narodowej, emocjonalnej wspólnocie pamięci. Moim zdaniem nie jest to możliwe, gdyż gra wyobraźni między doświadczeniem a jego przeżyciem toczy się nieustannie, a jej podłożem jest świadomość utraty i trudny do pokonania dystans oddzielający podmiot od przedmiotu nostalgicznej tęsknoty. Oddaję głos Adamowi Zagajewskiemu, autorowi eseju Czy należy odwiedzać miejsca święte, który napisat po pobycie we Lwowie w 2001 roku:

Przedziwna sytuacja: być w mieście, które jest nieomal, po mandelsztamowsku, „znajome do łez, do migdałków, do żył", ale wypełnione przez zupełnie inny, obcy tłum. Nawet nie inny niż ten, który się znało, bo przecież nie mogę powiedzieć, że znałem przedwojenny lwowski tłum - ale inny niż na przykład tłum krakowski czy warszawski, czy nawet gliwicki. Pogrążony we śnie idę ulicą, tonącą w jaskrawym słońcu. Na przedwojennym planie miasta, przysłanym przez ojca, sprawdzam nazwy ulic, nie biorąc zbyt poważnie nowego, ukraińskiego nazewnictwa. Tak samo zapewne chodzą po Gdańsku i po Wrocławiu niemieccy turyści; pogrążeni we śnie, ignorując aktualność miasta. Podobnie też muszą chodzić po krakowskim Kazimierzu młodzi amerykańscy czy izraelscy Żydzi, szukający śladów przedwojennego życia; pogrążeni we śnie. Jesteśmy jak duchy, niecierpliwie odpędzające to, co realne - czyli nowe życie. Ponieważ nowe życie w starych miastach wydaje nam się niedoskonałe, przypadkowe, prowizoryczne i właściwie niepotrzebne ${ }^{89}$.

\footnotetext{
${ }^{88}$ Boym 2001, s. 10 i n.

${ }^{89}$ Zagajewski 2001.
} 


\section{Bibliografia}

Alexander J. C. 2004, Toward a Theory of Cultural Trauma [w:] Alexander J. C., Eyerman R., Giesen B., Smelser N. J., and Sztompka P.., Cultural Trauma and Collective Identities, University of California Press, Berkeley, pp. 1-30.

Anderson B. 1991, Wspólnoty wyobrażone, Znak, Kraków.

Bednarek S. 1996, W kregu matych ojczyzn, szkice regionalistyczne, Dolnośląskie Towarzystwo Społeczno-Kulturalne, Krajowy Ośrodek Dokumentacji Regionalnych Towarzystw Kultury, Rada Krajowa Regionalnych Towarzystw Kultury, Wrocław-Ciechanów.

Boym S. 2001, The Future of Nostalgia, Basic Books, New York.

Dziedzic I. 1992, Teraz ja... 99 pytań do mistrzyni telewizyjnego wywiadu, Oficyna Wydawnicza Reporter, Warszawa.

Eggers-Dymarski J., Gizewska J., Lenk K., Pfeifer G. 2005, Pomiędzy starq a nowa ojczyzna: Lworwianie we Wroctawiu [w:] Ther P., Królik T., Henke L. (red.), Das polnische Breslau als europäische Metropole - Erinnerung und Geschichtspolitik aus dem Blickwinkel der Oral History I Polski Wroctaw jako metropolia europejska - Pamięć i polityka historyczna z punktu widzenia oral history, Oficyna Wydawnicza ATUT, Wrocław, https://homepage.univie.ac.at/philipp. ther/breslau/html/pomiedzy.html, 11.11.2018.

Fiałkowski T. 2000, Świat na krawędzi. Ze Stanistawem Lemem rozmawia..., Wydawnictwo Literackie, Kraków.

Golka M. 2009, Pamięć spoteczna i jej implanty, Wydawnictwo Naukowe Scholar Warszawa.

Kościk B. 1999, Z Jerzym Madeyskim historykiem sztuki, publicysta rozmawia..., „Cracovia Leopolis" nr 3, http://www.cracovia-leopolis.p1/index.php?pokaz=rozmowy, 9.09.2018.

Kubicki P. 2010, Miasto w sieci znaczeń. Kraków i jego tożsamości, Księgarnia Akademicka, Kraków. Kurczewska J. 2016, Wspólnoty pamięci lokalnej i narodowej. Kilka uwag o ich zbiorowym wytwarzaniu à la polonaise, „Teksty Drugie” nr 6, s. 30-51.

Malatyńska M. 2016, Mistrzowska lekcja Wojciecha Pszoniaka, „Kraków” nr 7/8 z dn. 15.07., http://www.e-teatr.pl/pl/artykuly/225803,druk.html, 11.11.2018.

Nijakowski L.M. 2008, Polska polityka pamięci, esej socjologiczny, Wydawnictwa Akademickie i Profesjonalne, Warszawa.

Nowak J. 2011, Spoteczne reguty pamiętania. Antropologia pamięci zbiorowej, Nomos, Kraków.

Paquot T. 2006, Marc Augé w rozmowie przeprowadzonej przez ..., tłum. I. Kuźma, „Journal of Urban Ethnology" Nr 8, s. 5-18.

Purchla J. 1996, Kraków - prowincja czy metropolia?, Universitas, Kraków.

Pencakowski P. 2006, Tylko we Lwowie, „Renowacje i Zabytki” nr 3, s. 23-50.

Rosenwein B. 2006, Emotional Communities in the Early Middle Ages, N.Y. Cornell University Press, Ithaca 2006.

Rosenwein B. 2010, Problems and Methods in the History of Emotions, https://www.passionsincon text.de/index.php/?id=557

Schütz A. 2012, O wielości światórw. Szkice z socjologii fenomenologicznej, Zakład Wydawniczy Nomos, Kraków 2012. 
Smelser N. J. 2004, Psychological trauma and cultural trauma [w:] Alexander J. C., Eyerman R., Giesen B., Smelser N. J., and Sztompka P.., Cultural Trauma and Collective Identities, University of California Press, Berkeley, s. 31-59

Suleja W. 2001, Historia Wroctawia. W Polsce Ludowej, PRL i III Rzeczypospolitej, Wydawnictwo Dolnośląskie, Wrocław.

Sztompka P. 2000, Trauma wielkiej zmiany, Instytut Studiów Politycznych PAN, Warszawa.

Sztompka P. 2002, Socjologia. Analiza spoteczeństwa, Znak, Kraków.

Śliwiak T. 2018, Krakowski szlak bajkoteki, Stowarzyszenie Przyjaciół Nowej Huty, Kraków.

Ther P. 2005, Wstęp. Miasto odkrywane ponownie [w:] Ther P., Królik T., Henke L. (red.) Das polnische Breslau als europäische Metropole - Erinnerung und Geschichtspolitik aus dem Blickwinkel der Oral History / Polski Wroctaw jako metropolia europejska - Pamięć i polityka historyczna z punktu widzenia oral history, Oficyna Wydawnicza ATUT, Wrocław - https:// homepage.univie.ac.at/philipp.ther/breslau/html/wstep.html, 11.11.2018.

Thum G. 2005, Obce miasto Wroctaw 1945 i potem, Via Nova, Wrocław.

Zagajewski A. 2001, Czy należy odwiedzać miejsca święte?, http://www.ji-magazine.lviv.ua/ HBSconf-may2001/texts/zagaj-lwow.htm, 11.2017.

Zagajewski A. 2002, Obrona żarliwości, Wydawnictwo a5, Kraków.

Zagajewski A. 2007, Dwa miasta, Fundacja Zeszytów Literackich, Warszawa.

Zieliński Z. J. 1995, Z Polski do Polski, „Kresy Literackie” nr 1-2, s. 27-33.

Żygulski Z. jun. 2003, Druga wojna światowa w doświadczeniu Krakowa i Lwowa [w:] Purchla J. (red.) 2003, Kraków i Lwów w cywilizacji europejskiej. Materiaty międzynarodowej konferencji zorganizowanej w dniach 15-16 listopada 2002, Międzynarodowe Centrum Kultury w Krakowie, Kraków, s. 113-124.

\section{Źródła}

Majewski J. 2017, To nie jest Lwów, który znatem. Rozmowa w: Polskie Radio Dwójka Poranek Dwójki, emisja 27.07., https://www.polskieradio.pl/8/404/Artykul/1794671,JanuszMajewski-to-nie-jest-Lwow-ktory-znalem, 27.08.2017.

Paluch J. M. 1997, Z Bogustarwem Schaefferem rozmawia ..., „Cracovia Leopolis” nr 1, http://www. cracovia-leopolis.pl/index.php?pokaz=rozmowy, 9.09.2018.

Paluch J. M. 2003, Ze Stefanem Berdakiem rozmawia..., „Cracovia Leopolis” nr 2, http://www. cracovia-leopolis.pl/index.php?pokaz=rozmowy, 9.09.2018.

Paluch J. M. 2006, Rozmowa z Romq Krzemień, „Cracovia Leopolis” nr 3, http://www.cracovia -leopolis.pl/index.php?pokaz=rozmowy, 9.09.2018.

Paluch J. M. 2007, Z Adamem Macedońskim rozmawia ..., „Cracovia Leopolis” nr 2, http://www. cracovia-leopolis.pl/index.php?pokaz=rozmowy, 9.09.2018.

Paluch J. M. 2013, Z prof. Kazimierzem Wiechem rozmawia ..., „Cracovia Leopolis” nr 1, http:// www.cracovia-leopolis.pl/index.php?pokaz=rozmowy, 9.09.2018.

Paluch J. M. 2017, Andrzej Chlipalski, „Cracovia Leopolis” nr 2, http://www.cracovia-leopolis.pl/ index.php?pokaz=rozmowy, 9.09.2018. 
Pszoniak W. 2011, Cebulaki mojej matki, wywiad przeprowadził T. Lubelski 01.06., https://www. tygodnikpowszechny.p1/cebulaki-mojej-matki-139607, 9.09.2018.

Pszoniak W. 2018, Pasje gotowania odziedziczyt po matce, wywiad przeprowadziła E. Modrzejewska, „Retro” nr 9 (46), s. 14-15.

Tuzow-Lubański E. 1996, Spotkanie ze Stanistawem Lemem, „Przegląd Polski” - tygodniowy dodatek literacko-społeczny nowojorskiego „Nowego Dziennika” z dn. 9.V. Przedruk wywiadu: http://www.lwow.home.pl/semper/lem.html, 2.11.2017.

Widok Krakowa/View of Krakow 2013, film w ramach międzynarodowej serii City(W)rites, narrator A. Zagajewski, reżyseria M. Piekorz, producent Krakowskie Biuro Festiwalowe. Polski odcinek powstał w ramach projektu Reading Małopolska - https://www.youtube.com/ watch?v=BII6p3fjM8g, 21.01.2018).

Zagajewski A. 2015, Lwów zostawmy już Ukraińnom, wywiad przeprowadziła D. Subbotko, „Magazyn Świąteczny Gazety Wyborczej” z dnia 14. 02., http://wyborcza.p1/magazyn/ 1,124059,17406502,Adam_Zagajewski__Lwow_zostawmy_juz_Ukraincom.html, 19.08.2017.

Zborek M. 2001, Wspomnienia profesor Marii Podrazy-Kwiatkowskiej. Archiwum Uniwersytetu Jagiellońskiego, http://www.archiwum.uj.edu.pl/maria-podraza-kwiatkowska, 14.01.2019. 